\title{
Preoperative nursing consultation and self-care of cancer patients with respiratory ostomy
}

\section{Consulta pré-operatória de enfermagem e o autocuidado do paciente oncológico com estomia respiratória}

\section{Consulta de enfermería preoperatoria y autocuidado de pacientes oncológicos con estoma respiratório}

Renata Otoni Neiva ${ }^{1, *}$, Márcio Corrêa Nogueira ${ }^{2}$, Adriana Jimenez Pereira $^{3}$

\section{ORCID IDs}

Neiva RO (iD https://orcid.org/0000-0001-9622-5711

Nogueira MC (D) https://orcid.org/0000-0001-7964-632X

Pereira AJ (D) https://orcid.org/0000-0002-5348-3945

\section{COMO CITAR}

Neiva RO; Nogueira MC; Pereira AJ. Preoperative nursing consultation and self-care of cancer patients with respiratory ostomy. ESTIMA, Braz. J. Enterostomal Ther., 2020, 18: e2920. https://doi.org/10.30886/ estima.v18.914_IN

\begin{abstract}
Objective: to demonstrate the influence of the preoperative nursing consultation in the practice of self-care performed by patients with respiratory ostomy at the A.C. Camargo Cancer Center and to describe what are the self-care practices performed and their limiting factors. Method: qualitative, exploratory study, carried out with 7 patients aged 18 years or older, who underwent preoperative nursing consultation, who underwent surgery with the manufacture of a respiratory ostomy and were able to establish verbal communication. Data was collected through semi-structured interviews and a digital recorder and submitted to content analysis. Results: male participants predominated, aged 56 years or over and completed high school. Two analytical categories were identified: "Repercussions of the actions promoted by the preoperative nursing consultation"; and "Obstacles in the search for autonomy in the care of the tracheostomy cannula". Conclusion: nursing consultation is an important instrument to guide, form bonds and clarify doubts about care with ostomy and respiratory devices, and nursing actions can limit and even prevent the patients from developing their self-care, making it necessary that the therapeutic nursing project is planned to aggregate the patient in this process.
\end{abstract}

DESCRIPTORS: Nursing in the office; Oncology nursing; Self-care; Surgical stomas; Tracheostomy; Stomatherapy.

\footnotetext{
1. A.C. Camargo Câncer Center - Departamento de Cabeça e Pescoço - Ambulatório de Curativos - São Paulo (SP), Brazil.

2. Centro Universitário São Camilo - Departamento de Pós-Graduação Lato Sensu Enfermagem em Estomaterapia - São Paulo (SP), Brazil.

3. Centro Universitário São Camilo - Departamento de Enfermagem - São Paulo (SP), Brazil.

*Correspondence author: renata_otoni@hotmail.com

Received: Jul. 01, 2020 | Accepted: Nov. 11, 2020
} 


\section{RESUMO}

Objetivo: demonstrar a influência da consulta pré-operatória de enfermagem na prática do autocuidado realizado pelos pacientes com estomia respiratória do A.C. Camargo Câncer Center e descrever quais são as práticas de autocuidado realizadas e seus fatores limitadores. Método: estudo qualitativo, exploratório, realizado com 7 pacientes com idade igual ou superior a 18 anos, submetidos à consulta pré-operatória de enfermagem, que realizaram cirurgia com confecção de estomia respiratória e estavam com capacidade de estabelecer comunicação verbal. Os dados foram coletados mediante entrevista semiestruturada e gravador digital e submetidos à análise de conteúdo. Resultados: predominou participantes homens, com idade igual ou superior a 56 anos e $3^{\circ}$ grau completo. Foram identificadas duas categorias analíticas: "Repercussões das ações promovidas pela consulta pré-operatória de enfermagem"; e "Obstáculos na busca pela autonomia no cuidado com a cânula de traqueostomia". Conclusão: a consulta de enfermagem é um importante instrumento para orientar, formar vínculo e esclarecer dúvidas sobre os cuidados com a estomia e dispositivos respiratórios, e as ações de enfermagem podem limitar e até impedir o paciente de desenvolver o seu autocuidado, fazendo-se necessário que o projeto terapêutico de enfermagem seja planejado para agregar o paciente nesse processo.

DESCRITORES: Enfermagem no consultório; Enfermagem oncológica; Autocuidado; Estomas cirúrgicos; Traqueostomia; Estomaterapia.

\section{RESUMEN}

Objetivo: demostrar la influencia de la consulta preoperatoria enfermería en la práctica del autocuidado realizado por pacientes con estoma respiratoria en el AC Camargo Cancer Center, describa qué prácticas de autocuidado se realizan y sus factores limitantes. Método: estudio cualitativo, exploratorio, realizado con 7 pacientes de 18 años o más, que fueron intervenidos de consulta de enfermería preoperatoria, quienes fueron intervenidos con la fabricación de un estoma respiratorio, y pudieron establecer comunicación verbal. Los datos se recopilaron mediante entrevistas semiestructuradas y una grabadora digital, y se sometieron a análisis de contenido. Resultados: predominó el sexo masculino, de 56 años o más, y bachillerato completo. Se identificaron dos categorías analíticas: "Repercusiones de las acciones promovidas por la consulta de enfermería preoperatoria"; y "Obstáculos en la búsqueda de autonomía en el cuidado de la cánula de traqueotomía". Conclusión: la consulta de enfermería es una herramienta importante para orientar, vincular y aclarar dudas sobre el cuidado con el estoma y los dispositivos respiratorios, y las acciones de enfermería pueden limitar e incluso impedir que el paciente desarrolle su autocuidado, haciéndolo necesario que el proyecto de enfermería terapéutica está planificado para agregar al paciente en este proceso.

DESCRIPTORES: Consulta de enfermería; Enfermería oncológica; Cuidados personales; Estomas quirúrgicos; Traqueotomía; Estomaterapia.

\section{INTRODUCTION}

Head and neck cancer comprises a group of malignant neoplasms that originate in the oral cavity, oropharynx, larynx and hypopharynx, being often described as "squamous cell carcinoma of the upper aerodigestive tract (UADT)"

Worldwide, it is the 6 th most prevalent type of cancer with $9.2 \%$ of cases, being responsible for $4.6 \%$ of cancer-related deaths. In Brazil, it is associated with high mortality, occupying the fifth place in the cause of death. The Instituto Nacional do Câncer-INCA estimated for the year 2020, in Brazil, the appearance of 15,190 new cases of cancer in the oral cavity, occurring 11,180 cases in men and 4,010 cases in women ${ }^{1,2}$.

The best-established risk factors for the development of these types of cancers is tobacco consumption associated or not with the use of alcohol, and other risk factors, such as unprotected sun exposure for lip cancer, occupational exposure and the virus also related to Human Papilloma $(\mathrm{HPV})^{1,2}$.
In more than $60 \%$ of patients, the diagnosis of head and neck cancer occurs when the disease is in advanced clinical stages, this is because the first symptoms presented are of a non-specific nature and, also, due to the fact that they can access the lymphatic channels in the beginning of its appearance and develop quickly. Thus, patients with advanced disease need more complex treatment, with the association of different therapeutic modalities, such as surgery, radiotherapy and chemotherapy, and consequently with greater morbidity and impaired quality of life $\mathrm{e}^{1,3}$.

In order to maintain a patent airway in the treatment of head and neck cancer, many patients required, temporarily or permanently, a tracheostomy. This procedure consists of an opening in the anterior wall of the trachea (respiratory ostomy), which communicates with the external environment through a cannula, generating changes in the breathing dynamics of the individual, as well as in his behavior, interpersonal relationship and personal care ${ }^{4}$.

The unique needs and reactions of an ostomy patient are implied in their identity and subjectivity. Thus, the problems caused by the opening of an ostomy are related 
to the personal conditions of each individual, including the quality of the care support received in the stages of surgical treatment that generates the ostomy.In this context, the nursing consultation (NC) stands out, a private activity of the nurse, supported by law, relevant and resolving, which identifies health / disease situations, prescribes and performs nursing actions that contribute to health promotion, disease prevention and protection, in addition to the recovery and rehabilitation of the individual, family and community ${ }^{5}$.

The nursing consultation that precedes the procedure that generates a respiratory ostomy is an important therapeutic tool, which provides the patient with a space to clarify their doubts and/or that of their families. Within his scope of action, at this moment, the nurse brings information about the surgical procedure, the respiratory ostomy and its devices and other topics that he deems necessary, aiming to reduce the immediate surgical complications, establish a link and identify problems, in addition to providing a opportunity for early health education on the importance of self-care in the postoperative period, in an accessible language.

This study is justified by the scarcity of research related to preoperative nursing consultation in promoting self-care of cancer patients with respiratory ostomy. The questions were as follows: does the preoperative nursing consultation contribute to the development of self-care for cancer patients with respiratory ostomy? What are the self-care practices performed by these patients?

\section{OBJECTIVE}

Demonstrate the influence of the preoperative nursing consultation on the practice of self-care performed by patients with post-surgical respiratory ostomy at the AC Camargo Cancer Center, and describe, from the content analysis, what are the practices performed and the limiting factors for the development of autonomy in self-care.

\section{METHOD}

This is a qualitative, exploratory study, carried out at the Department of Head and Neck Surgery at A.C. Camargo Cancer Center, an oncology center located in the city of São Paulo. The A.C. Camargo Cancer Center is a private, non-profit institution maintained by the Antônio Prudente foundation, which treats cancer patients from the Unified Health System (Sistema Único de Saúde-SUS), insurance companies ( health insurance) and private patients. This research was conducted according to the ethical precepts of Resolution No. 466/12 CNS/MS. The collection was initiated after approvals by the Research Ethics Committee with Human Beings of Centro Universitário São Camilo and by the Research Ethics committee of A.C. Camargo Câncer Center, under number 2635/18.

The patients eligible for the study were selected from February/2018 to April/2018. Seven patients aged 18 years or older were included, who underwent preoperative nursing consultation established by the institution, who were in the postoperative period of head and neck surgeries assessed as major (resection of tumors and/or tongue and other tumors in the oropharyngeal region), which required transient respiratory ostomy and who were in an outpatient rehabilitation process with the ability to establish verbal communication. Total laryngectomized patients were excluded because they were not yet rehabilitated for verbal communication and those who had a respiratory ostomy reversal before the seventh postoperative day, because it's believed that a period shorter than this would be insufficient to develop self-care.

Initially, a registration document of all patients who underwent the preoperative nursing consultation in the head and neck department was accessed. After that, through the MV platform, a computerized system used to record the medical records of patients at the A.C. Camargo Cancer Center, the information of these patients was consulted, and those eligible were selected according to the inclusion criteria. The schedule of their outpatient return visits was investigated according to the schedule of consultations and procedures. The selected patients and those who attended, as scheduled, were approached after carrying out the scheduled procedures and invited to participate in the research, being informed about the context, methods of the research and their risks. Thus, after clarifying the study, they were asked to read and sign the Free and Informed Consent Form (FICF) in two copies, to confirm the information and agree to participate. One of the copies being delivered to the participant and the other filed by the researcher. All invited patients agreed to participate in the research. 
After signing the consent form, the patient was treated in an appropriate environment, accompanied by his family member/caregiver and the researcher for the application of a specific, semi-structured questionnaire, composed of open and closed questions, contemplating the objective of the study. In addition, a digital recorder was used to facilitate the subsequent transcription and analysis of its content. The interviews lasted an average of 30 minutes.

The transcriptions were performed later, requiring repetition of the audios from three interviews, as the diction of these participants was compromised by the surgical procedure. The data were discussed and worked from the content analysis. Such a technique consists of interpreting the meaning of what is said on a given subject by categorizing the content of the reports. The content was analyzed according to the following phases: pre-analysis - with the choice and organization of the material to be analyzed and formulation of the hypotheses; exploration which consists of transforming data and record units into context units; and analysis - with the treatment of results, interpretations and conclusions ${ }^{6}$.

\section{RESULTS}

The sample of this study was composed of seven participants, whose characterization is shown in Table 1.

Table 1. Cancer patients from the A.C. Camargo Câncer Center. São Paulo (SP), Brasil - 2018.

\begin{tabular}{|c|c|c|}
\hline Gender & $\begin{array}{l}\text { Number/ } \\
\text { Age }\end{array}$ & $\begin{array}{l}\text { Median/ } \\
\text { Fraction \% }\end{array}$ \\
\hline Male & 5 & $71 \%$ \\
\hline Female & 2 & $29 \%$ \\
\hline Age & $\begin{array}{c}\text { Number/ } \\
\text { Age }\end{array}$ & $\begin{array}{l}\text { Median/ } \\
\text { Fraction \% }\end{array}$ \\
\hline E1 & 38 & \\
\hline E2 & 19 & \\
\hline E3 & 68 & \\
\hline E4 & 57 & 47 anos \\
\hline E5 & 55 & \\
\hline E6 & 57 & \\
\hline E7 & 36 & \\
\hline $\begin{array}{l}\text { Respiratory ostomy } \\
\text { time }\end{array}$ & $\begin{array}{l}\text { Number/ } \\
\text { Age }\end{array}$ & $\begin{array}{l}\text { Median/ } \\
\text { Fraction \% }\end{array}$ \\
\hline 7 to 14 days & 3 & $43 \%$ \\
\hline 15 to 21 days & 2 & $28.5 \%$ \\
\hline 22 to 28 days & 2 & $28.5 \%$ \\
\hline
\end{tabular}

After reading the speeches collected in the interviews, two analytical categories were identified: "Repercussions of the actions promoted by the preoperative nursing consultation" and "Obstacles in the search for autonomy in the care of the tracheostomy cannula".

\section{Repercussions of the actions promoted by the preoperative nursing consultation}

The preoperative nursing consultation for patients in the head and neck department was implemented at the institution in November 2017. In this approach, the stoma nurse practitioners who work in the sector present to the patients and family members, among other subjects, the definition of tracheostomy, ostomy respiratory system and its devices. As instruments that facilitate the practice of health education developed, information leaflets are used with the types of tracheostomy cannulae used in the institution and their handling is demonstrated. The necessary care for the device is also addressed, such as: hygiene of the intermediate or endocannula, replacement of dressings for tracheostomy and disposable fixatives.

“(...)The matter of cleaning, right? So, in the room, I already asked to clean it because I knew it was needed, right?”. E1

“(...)As for hygiene, what had to be done. Remove the cannula to wash, sanitize, right? So I was attentive to everything that was taught to me, but it was all done accordingly". E5

“(...) They explained everything to me about how to handle the cannula. They showed the types of cannulas, the evolution that would have, you know, changing one for the other. It happened. They even explained to me what the powders would be, if I left here there was even a protection that could be placed. They showed me the device too". E6

Head and neck surgery with respiratory ostomy determines psychological and functional changes, as in swallowing and speech, which are very significant for the patient, which can cause physical, emotional and social sequelae. It is the beginning of a process of dependence on the tracheostomy cannula, a condition that can generate insecurity, fear and embarrassment due to the evidence of the device and the presence of secretions. Education and guidance actions are necessary to prepare this individual to face this new condition, 
offering him information and knowledge to acquire skills and develop their self-care.

In this context, the relevance of nurses as educators in the preoperative period is observed. It is seen in the statements that the guidelines provided contributed to a better perception and preparation of patients.

“(...) Ah, I didn't know anything, right? So it already gave me a good idea of what was going to be". E1

“(...) I was very well attended, very well assisted. At this point you did a lot, I just have to thank you. They were very important (the information)". E3

“(...) Everything was within what I was told, and it was good. Because you already know the path you will face". E4

“(...)The care that had to be done, everything was given to me before". E5

“(...) I managed to assimilate everything because of what you said”. E7

Some interviews also presented the difficulties that patients faced in this care process and mentioned that some factors were not addressed in the preoperative nursing consultation:

“(...)But it was very difficult to breathe a little. At the time of cleaning, then take out and pour water, I felt drowned (tracheal aspiration)". E2

“(...)the biggest problem with the cannula for me was the first time it got stuck with a stitch, so it caused me a wound that hurt a lot". E4

“(...) I just think they should tell us more about when to remove the cannula, about the need to always squeeze when it comes to coughing, to speak, because I had a great difficulty in closing it". E4

In head and neck surgeries with microsurgical reconstruction, tracheostomy cannulas are fixed to the patient's skin with suture stitches for a predetermined period. The purpose of this approach is to prevent complications with the surgical flap. After decannulation, the ostomy edges are approached with adhesive tape and subsequent occlusion with a compressive dressing to promote healing.

It was also possible to note that the new health condition, when emotionally impacting patients, arouses conflicting feelings and that influences the understanding of the guidelines performed by the nurse in the educational process, as described in the following speech:
“(...) yes, it gave a vision, it's good that I expected it. I just remembered I wouldn't have a voice, the rest I didn't pay much attention, no.”. E2

\section{Obstacles in the search for autonomy in the care of the tracheostomy cannula}

Most respondents reported that care for the tracheostomy cannula was performed by the nursing team and/or family members, as evidenced in the following excerpts from the interviews:

“(...) I was with my sister. Sometimes she or the nurse (performed stoma care)". E1

“(...)it wasn't me doing it, it was the nursing staff. I didn't get to do maintenance alone, secretion was always coming out, I always called someone to do it". E3

“(...) it was when I was in the hospital and they did it in the hospital. So the whole process was with the nurses, hygiene was up to them. I only spoke when it was bothering me, you know, then they would take it out and clean it, the cleaning was up to them. I didn't do it, it was the nurses. I was hospitalized and everything...”. E5

“(...) I didn't touch it, I didn't put my hand on my stoma. The nurses did it, or it was him (husband)". E7

The presence of a respiratory ostomy modifies the respiratory anatomy and physiology of the individual, requiring new skills to develop self-care. It was found that in order to provide assistance and support family participation in patient care, professionals are at risk of enabling dependence, compromising the development of the individual's self-care with the new health condition.

It is important that for the development of self-care, the patient demonstrates determination and desire to perform it. In this scenario, the educational work of nursing is fundamental to encourage, stimulate and improve the patient's skills in achieving their autonomy.

In situations where respondents took care of the tracheostomy cannula, these activities were shared with the nursing staff.

“(...) when I managed to remove it (the intermediate), yes, I did it, but not alone, right? There was the nurse on the side. Oh, the one who held it like this, and I could change it, or the nurse would change it and I would hold". E2 
"(...) the little manhole, the one that comes out right? I was able to take it out and clean it during hospitalization, but most of the time the nursing staff did it, right?". E6

In the only report on the performance of self-care with autonomy, it was identified that there was already a previous experience of the patient with the use of the tracheostomy cannula, a fact that contributed to greater safety and ability to handle the device.

“(...) I did the cleaning myself. I was able to open, remove it and clean it. I looked in the mirror and cleaned up what was possible". E4

\section{DISCUSSION}

As for the profile of the participants, it was evident that the largest contingent is composed of male patients, aged 56 years or over. The data found corroborate the existing studies in the literature that show a higher incidence of head and neck cancer in men. Generally these individuals are between 50 and 60 years of age, although in cancers associated with the HPV virus, it is possible to observe a reduction in age range $e^{1,3,7}$.

With regard to research limitations, the number of participants that was made unfeasible due to the time limit established for data collection and the complexity of major head and neck surgeries, which limited the patient participation due to the inclusion criteria established in this study. Considering the sample size, the results should be observed with caution. However, the findings found in this study on self-care with respiratory ostomy support and are in agreement with the little literature identified on the subject.

In the category "Repercussions of the actions promoted by the preoperative nursing consultation", the speeches of the patients focused the approach on the relevance of the nursing consultation and reinforced the importance of the guidelines provided, which enabled knowledge about the respiratory ostomy and the necessary care, such as hygiene of the tracheostomy cannula and safety on the handling of such devices. These results show the preoperative nursing consultation as a relevant work tool for nurses, highlighting their role as a health educator.

It is known that the condition of having a respiratory ostomy alters the perception of the patient's body image and generates changes in their lifestyle and in the development of their daily activities. These perceptions and coping mechanisms in the face of the new health condition are factors that are conditioned to culture, age, quality of family and care support received in all stages of treatment ${ }^{8}$.

In the category "Obstacles in the search for autonomy in the care of the tracheostomy cannula", it was observed that the majority of patients reported that care for the respiratory ostomy was performed by the nursing team and/or caregivers. In this context, the nurse is trained and responsible for correctly assessing the patient and carrying out the systematization of nursing care (SNC), managing possible care risks and managing the care and assistance of the nursing team. The therapeutic plan consists of cleaning the peristomal skin, maintaining and changing the dressings for tracheostomy, as well as replacing the cannula set, cleaning the endocannula and aspirating tracheal secretion when necessary, in order to avoid the appearance of injuries and ensure a safe and contamination-free environment ${ }^{9}$.

Thus, the care provided to patients is undoubtedly important, but some of them must be gradually transferred to the person with an ostomy so that the subject gains confidence and develops skills and abilities to perform selfcare, resuming their daily activities and contributing to a better quality of life.It is the obstacles that people with an ostomy encounter to establish self-care with an ostomy that can determine dependence on their family members and / or health professionals ${ }^{10}$.

The teaching of self-care should start in the preoperative period, right after the decision on the surgical approach to be performed. The nurse must use teaching-learning resources to establish a bond with the patient/caregiver to facilitate a better understanding of the physical and functional changes resulting from the creation of a respiratory ostomy. In the postoperative period, care is taken with the ostomy, the peristomal skin, cleaning and replacement of the devices, with the patient being the protagonist in this scenario in which they must clarify doubts and demonstrate their skills for home self-care. During this period, he better understands the information provided in the preoperative period, which may contribute to his physical and psychological adjustment, better recovery, adequacy and success in self-care. These guidelines must be continuous and centered on the difficulties of patients and their families/caregivers ${ }^{11}$.

Through the bond established with the patient, the nurse can know what are the difficulties encountered in the practice of self-care, being able to define, within their 
scope of action, health measures and actions in order to meet their needs.

It is also up to the nurse, within this context, to evaluate the patient regarding the development of the necessary skills for the management of the ostomy and respiratory devices. Thus, it is important to delimit the competences to be developed in the short, medium and long term so that the professional can correctly diagnose which stage the patient is in and through an evaluation delimit new objectives to be achieved or readjust and redirect the previous objectives to the patient during the process of building self-care. When performing self-care safely, the patient gains autonomy and gets organized in their daily routine ${ }^{12}$.

Another factor observed in the category "Obstacles in the search for autonomy in the care of the tracheostomy cannula" and which is intrinsically related to the development of self-care is regarding the period of permanence of the respiratory ostomy. With the progression in the rehabilitation process, the patient evolves with respiratory mechanics and adequate swallowing, without obstruction of the upper airways and controlled secretions, then decannulation begins. The decannulation process can be variable, according to routines established in different services, but it usually starts with deflating the cuff, and if the patient has good tolerance, the plastic cannula is replaced by a metal one until the tracheostomy cannula is removed. and an occlusive dressing of the stoma is performed ${ }^{13,14}$.

Individuals with temporary ostomies are less involved in self-care, as they use escape and denial mechanisms as coping strategies in the face of the ostomy. Individuals with permanent respiratory ostomies develop self-care skills more prematurely by using confrontational strategies in the face of their new health condition. It is noteworthy that, among other factors, the type of ostomy in terms of duration (temporary / definitive) and the time elapsed from the surgery may relate the psychological adaptation to the ostomy with the development of self-care competence ${ }^{15}$.

\section{CONCLUSION}

The manufacture of a respiratory ostomy is a therapeutic resource widely used in order to maintain the respiratory functionality of patients with cancer who are undergoing major head and neck surgery. This study demonstrated the importance of preoperative nursing consultation as an instrument for guidance, bonding and as an important space for patients and family members to resolve any doubts and concerns regarding the process of care of the ostomy and respiratory devices, as well as promotion of self-care.

It was observed that the nursing actions can limit and even prevent the patient from developing and appropriating his selfcare, because when performing the care with the respiratory ostomy without including the individual in this process, health education does not work seeking the subjects' autonomy. This finding signals the nurse's need to manage nursing care in order to add the patient to the care, so that they participate in the actions dispensed to the respiratory ostomy and its devices, developing the necessary skills to appropriate self-care.

With the scarcity of content found during the construction of this study, it is necessary to develop a greater contingent of research on this topic in order to provide scientific research of quality and clinical importance, which directs the performance of nursing in the entire therapeutic process of the patient with respiratory ostomy, either through the preoperative nursing consultation or during the systematization of nursing care in the postoperative period.

\section{AUTHOR'S CONTRIBUTION}

Conceptualization: Neiva RO, Nogueira MC and Pereira AJ; Methodology: Neiva RO; Investigation: Neiva RO and Nogueira MC; Writing - First version: Neiva RO, Nogueira $\mathrm{MC}$ and Pereira AJ; Writing: Reviewing \& Editing: Neiva RO, Nogueira MC and Pereira AJ; Supervision: Pereira AJ

\section{REFERENCES}

1. Santos FBG, Leonhardt FD, Abrahão M. Prevenção do câncer do trato aerodigestivo superior através das estratégias de busca ativa e uso de propedêutica armada. Braz J Otorhinolaryngol 2020;86(4):443-9. https://doi. org/10.1016/j.bjorl.2019.01.002
2. Santos MO. Estimativa 2018: incidência de câncer no Brasil. Rev bras cancerol 2018;64(1):119-20. Avialble at: https:// www.inca.gov.br/tipos-de-cancer/cancer-de-boca

3. Foreman A, Gullane PJ. Overview of head and necks tumors. Plastic surgery. Volume 3. Craniofacial, Head and Necks 
Surgery and Pediatric Plastic Surgery, 16, 401-426.e2. December 31, 2017.

4. Soares MCCX, Westphal FL, Lima LC, Medeiros JM. Elaboração de protocolo de condutas em traqueostomias no hospital referência de tratamento do câncer do Amazonas. Rev Col Bras Cir 2018;45(4):e1744. https://doi.org/10.1590/01006991 e-20181744

5. Alexandre SG. Construção e validação de instrumentos para consulta de enfermagem à pessoa idosa estomizada fundamentados na teoria do autocuidado [tese]. Fortaleza (CE): Universidade Estadual do Ceará, Centro de Ciência da Saúde; 2017.

6. Silva AH, Fossá MIT. Análise de conteúdo: exemplo de aplicação da técnica para análise de dados qualitativos. Qualitas Revista Eletrônica 2015;17(1). Avialble at: http://revista.uepb.edu.br/index.php/qualitas/article/ view/2113/1403

7. Cocato ACF, Gomes JJ, Biasoli ER, Silva JZ, Miyahara GI, Neto SC. Fatores de risco da fístula faringocutânea em pacientes laringectomizados. ESTIMA, Braz J Enterostomal Ther 2016; [cited 2020 aug 13]; 13(3). Avialble at: https://www. revistaestima.com.br/estima/article/view/109

8. Souza MMT, Moraes AA, Balbino CM, Silvino ZR, Tavares CMM, Passos JP. Apoio emocional realizado por enfermeiro ao paciente ostomizado. Rev port enferm saúde mental 2016;esp4:49-56. https://doi.org/10.19131/rpesm.0141

9. Oliveira APV, Gomes GC, Romeu BR, Svaldi JSD, Machado GS. Protocolo assistencial de enfermagem a portadores de traqueostomia em ventilação mecânica. HU Revista, Juiz de
Fora 2016;42(1):33-41. Avialble at: https://periodicos.ufjf.br/ index.php/hurevista/article/view/2353

10. Mota MS, Gomes GC, Silva CD, Gomes VLO, Pelzer MT, Barros EJL. Autocuidado: uma estratégia para a qualidade de vida da pessoa com estomia. Investig Enferm Imagen Desarr 2016;18(1):63-78. https://doi.org/10.11144/Javeriana.ie181.aeqv

11. Lenza NFB, Sonobe HM, Buetto LS, Santos MG, Lima MS. O ensino do autocuidado aos pacientes estomizados e seus familiares: uma revisão integrativa. Rev bras promoç saúde 2013;26(1):139-45. Avialble at: https://www.redalyc.org/ pdf/408/40827988019.pdf

12. Queirós SMM, Santos CSVB, Brito MAC, Pinto IES. Construção do formulário de avaliação da competência de autocuidado na pessoa com ostomia de ventilação. Rev Enf Ref 2015;IV(7):51-60. https://doi.org/10.12707/RIV15010

13. Costa CC, Favero TC, Rosa FB, Steidl EMS, Mancopes R. Decanulação: atuação fonoaudiológica e fisiterapêutica. Distúrb comun 2016;28(1):93-101. Avialble at: https:// revistas.pucsp.br/index.php/dic/article/view/22714/19274

14. Côrte MMD, Vicente LCC, Friche AAL. Decanulação: indicadores sociodemográficos, clínicos e fonoaudiológicos preditivos de sucesso. Audiol Commun Res 2019;24:e2103. https://doi.org/10.1590/2317-6431-2018-2103

15. Queirós SMM, Santos CSVB, Brito MAC, Pinto IES. Factores condicionantes del desarrollo de la competencia de autocuidado en la persona con ostomía de ventilación. Rev Enf Ref 2017;IV(14):57-68. https://doi.org/10.12707/ RIV17010 